\title{
COMPETITIVITY OF THE COMMON-BEAN PLANT RELATIVE TO THE WEED ALEXANDERGRASS [Brachiaria plantaginea (Link) Hitch.]
}

\author{
Telma Passini1 ${ }^{1,4}$; Pedro Jacob Christoffoleti2,4*; Inês Fumiko Ubukata Yada ${ }^{3,4}$ \\ ${ }^{1}$ IAPAR, Área de Fitotecnia, C.P. 481 - 86001-970 - Londrina, PR - Brasil. \\ ${ }^{2}$ USP/ESALQ - Depto. de Produção Vegetal, C.P. 9 - 13418-900 - Piracicaba, SP - Brasil. \\ ${ }^{3}$ IAPAR, Área de Biometria, C.P. 481 - 86001-970 - Londrina, PR - Brasil. \\ ${ }^{4} \mathrm{CNPq}$ scholar. \\ *Corresponding author <pjchrist@esalq.usp.br>
}

\begin{abstract}
Methodologies of competitive interaction quantification between weeds and crops are not widely elucidated and compared in the literature. The competitive ability of common-bean (Phaseolus vulgaris) relative to alexandergrass (Brachiaria plantaginea) was assessed and two approaches of replacement series experiment analysis were compared. The response of the species to the presence of each other at different densities and proportion was evaluated. Replacement series at total densities of 625, 816 and 1,111 plants $\mathrm{m}^{-2}$ were performed at the proportions of common-bean:alexandergrass of 100:0 (pure stand of common-bean), $75: 25,50: 50,25: 75$ and $0: 100 \%$ (pure stand of alexandergrass), at four replicates in a randomized block design. Data analyses were performed by the qualitative compared to the quantitative approach. The quantitative approach provided larger number of information than did the qualitative approach, and indicated that there was intraspecific competition among common-bean plants, and a minimum of interspecific competition from alexandergrass. There was no intraspecific competition among alexandergrass plants, being the crop effect on the weed larger than the effect among alexandergrass plants. The ecological niche differentiation was partial, since the crop intraspecific competition was larger than the interspecific, and the last one was negligible, at the same time that the weed interspecific competition was larger than the intraspecific. Common-bean, as a competitor species, is superior to alexandergrass.

Key words: replacement series design, qualitative analysis, quantitative analysis
\end{abstract}

\section{COMPETITIVIDADE DO FEIJOEIRO-COMUM COM O CAPIM-MARMELADA [Brachiaria plantaginea (Link) Hitch.]}

\begin{abstract}
RESUMO: As metodologias de quantificação das interações competitivas entre plantas cultivadas e daninhas não estão amplamente elucidadas e comparadas na literatura. A competitividade da cultura de feijão-comum (Phaseolus vulgaris) em relação ao capim-marmelada (Brachiaria plantaginea) foi avaliada pela comparação entre o método qualitativo e um método quantitativo de análise de resultados. A resposta de cada espécie à presença da outra foi obtida em três séries substitutivas nas densidades totais de 625,816 e 1.111 plantas $\mathrm{m}^{-2}$. Em cada série, as proporções entre plantas de feijão-comum e de capim-marmelada foram de 100:0 (estande puro de feijão-comum), 75:25, 50:50, 25:75 e 0:100\% (estande puro de capim-marmelada). Os tratamentos foram dispostos em delineamento experimental de blocos ao acaso, com quatro repetições. O método quantitativo proporcionou maior número de informações que o qualitativo e evidenciou que para o feijãocomum houve competição intra-específica e mínima competição interespecífica do capim-marmelada. Não houve competição entre as plantas de capim-marmelada, sendo que, o efeito da cultura sobre a planta daninha foi maior que o efeito competitivo entre as plantas de capim-marmelada. A diferenciação de nicho ecológico foi parcial uma vez que a competição intra-específica da cultura foi maior que a interespecífica, sendo a última desprezível, ao mesmo tempo que a competição interespecífica sobre a planta daninha foi maior que a intra-específica. O feijão-comum, como espécie competidora, é superior ao capim-marmelada.
\end{abstract}

Palavras-chave: séries substitutivas, análise qualitativa, análise quantitativa

\section{INTRODUCTION}

Methodologies of competitive interaction quantification between crops and weeds are not widely elucidated and compared in the literature. Harper (1977), Oliver \& Buchanan (1986), and Rejmánek et al. (1989) described treatment designs for competition studies and Oliver \& Buchanan (1986) described their advantages and disadvantages. Later on, Cousens (1991) analyzed the critiques that some designs have received and concluded that even the simplest one is appropriate to the objectives of certain studies. Among the available de- 
signs to be used in competition studies, authors have mentioned the additive, replacement series, systematic and surface response designs. The replacement series have been used mainly to determine the best competitor of two species or biotypes and to understand how they interact to each other (Cousens, 1991). In this kind of design, the total density is held constant while the proportion between the two species is variable (Harper, 1977). Treatments are established from a pure stand of one species and plants are progressively replaced with plants of a second species up to a pure stand of the later one (Spitters, 1983). Besides the pure stand of each species, at the same density, a treatment with the proportion of 1:1 is frequently used (Connoly, 1988). The total density must be at least enough to satisfy the "constant final yield law", i.e., the total density of plants which captures all available environmental resources. At this condition, the total biomass yield is constant, even if there is an increment in the number of plants per unit area (Wit, cited by Roush et al., 1989). The interpretation of the results of an experiment conducted as a replacement series can be done by the conventional approach, qualitatively, and quantitatively, using mathematical equations.

The qualitative interpretation is performed by comparing observed and expected yields, with the latter being a linear function of species proportions in the mixture. The straight line that connects each species yield in the pure stand (100:0) to its zero yield $(0: 100)$ defines the expected yield, which is considered to represent the competitive equivalence response (CE) in which the intraspecific competition is equivalent to interspecific competition (Rejmánek et al., 1989).

The quantitative interpretation of results from a replacement series experiment started by the end of the 1950 's when a linear relation between the reciprocal yield per plant and the plant density was empirically determined (Kira et al., cited by Rejmánek et al., 1989). This relation was determined for one species, and later on that was expanded to a two-species mix to obtain a pair of linear equations (Ogawa, cited by Rejmánek et al., 1989). Other scientists, using the same principle, developed a pair of corresponding equations (Spitters, 1983; Jolliffe et al., 1984).

Comparing the reciprocal yield per plant method of Spitters (1983) to the double reciprocal yield method of Jolliffe et al. (1984), Roush et al. (1989) concluded that the first was simpler with regard to the measurement of the relative importance of the intra- and interspecific competition and more sensible to measuring the interaction between density and proportion of the species mixture. As alexandergrass is an important weed in commonbean crop, the competitiveness of these species was evaluated by comparing the qualitative to the quantitative approach to data analysis.

\section{MATERIAL AND METHODS}

Two experiments were conducted in a greenhouse, in Piracicaba, SP, Brazil. In the first, the plant density $\left(N\right.$ - plants $\left.\mathrm{m}^{-2}\right)$ to each species (common-bean and alexandergrass) in which the yield of shoot biomass per unit area $\left(Y-\mathrm{g} \mathrm{m}^{-2}\right)$ becomes independent of the density was determined, according to the "constant final yield law". From the results of this experiment, a second experiment was set to determine the competitiveness of both species.

The greenhouse temperature was regulated to a maximum of $25^{\circ} \mathrm{C}$ and the irrigation was done by sprinkling, every two hours, from $7 \mathrm{~h} 00$ to $17 \mathrm{~h} 00$, applying every day a total of $10 \mathrm{~mm}$ of water. In cloudy or rainy days the irrigation was done from $9 \mathrm{~h} 00$ to $15 \mathrm{~h} 00$.

Seeds of common-bean (Phaseolus vulgaris L.) and alexandergrass [Brachiaria plantaginea (Link) Hitchc.] were commercially acquired. The seeds of the 'Carioca' common-bean variety, with $80 \%$ germination and $98 \%$ purity, were treated with carboxin + thiran. Alexandergrass seeds showed, in the germination test, that the first plants emerged at the sixth day after seeding, and the emergence rate was 25 seedlings per $0.58 \mathrm{~g}$ of seed.

Plastic pots $(18.5 \mathrm{~cm}$ upper diameter, $14.0 \mathrm{~cm}$ lower diameter, and $15.0 \mathrm{~cm}$ height) were filled with a mixed substrate made up of a soil material, sand, rotten manure, and carbonized rice husk (3:1:1:0.5 volume proportions), and treated with methyl bromide to reduce the weeds. The number of plants of each species per pot was recorded at the harvest time. Shoots were cut off at the soil level, dried at $75^{\circ} \mathrm{C}$ for 48 hours and weighed.

\section{Density in which the species reaches the constant final yield}

Experiments were carried out in a randomized block design with four replicates. Common-bean and alexandergrass were studied separately at densities of 1 , $2,4,8,16,32$ and 64 plants per pot, which correspond to $37,74,149,297,595,1,190$ and 2,381 plants $\mathrm{m}^{-2}$. The population of 24 plants of common-bean per pot (892 plants $\mathrm{m}^{-2}$ ) was also studied. Pots were filled with the substrate up to $1.5 \mathrm{~cm}$ below the top of the border of the pot. Common-bean seeds were distributed on the surface of the substrate and covered with a portion of the substrate up to the top of the border of the pot. Alexandergrass seeds and a portion enough of the substrate to complete the volume of each pot were manually mixed in a plastic bag. Excess seeds were sown (12/14/1999) and plants were thinned twice $(12 / 20 / 1999$ and $12 / 22 / 1999)$ to the required densities. The final stand was recorded and shoots were harvested 20 days after seeding (01/03/2000). At that time, common-bean plants were at the V3 stage (CIAT, 1983), and the alexandergrass, at the 14 stage (Zadoks et al., 1974). 
Dry biomass yielded per unit area $(Y)$ and density $(N)$ were used to calculate the reciprocal of dry biomass yielded per plant $(1 / w=N / Y)$. These data were used to perform a linear regression analysis with $1 / w$ as the dependent variable and $N$ as the independent variable. The obtained coefficients were used to write the equation (eq.1) of the reciprocal of shoot dry biomass yield per plant (Spitters, 1983):

$$
\frac{1}{w}=b o+b 1 \times N
$$

and the equation (eq.2) of the total of dry biomass yielded:

$$
Y=\frac{N}{b o+b 1 \times N}
$$

where, $b_{0}$ represents the reciprocal of the biomass of an isolated plant; $b_{1}$ represents the rate of increase in $1 / w$ or the rate of decrease in $w$ related to the addition of each plant to the population, and it also is the reciprocal of the maximum biomass per unit area $\left(b_{l}=1 / Y_{\max }\right)$ when density $(N)$ tends to infinity; and $b_{I} / b_{0}$ expresses the increase of $1 / w$ relative to its value in the absence of competition and, therefore, it measures the intraspecific competitive stress (Spitters, 1983).

Once the data were adjusted to the hyperbolic equation (eq. 2), the minimum value of density in which $Y$ would be similar to $Y_{\max }$ was determined for each species. The differences among the observed $Y$ values and the value of $Y_{\max }$ were calculated for each density. The null hypothesis $\left(H_{0}\right)$ was that the average of each of these differences was equal to zero. To test the $H_{0}$, it was verified if the values of the differences present a normal distribution (W-test). Presenting normal distribution $[(\operatorname{Pr}<\mathrm{W})>0.05]$, the comparison was done by a t-test, accepting $H_{0}$ when $[(\operatorname{Pr}>|\mathrm{T}|)>0.05]$.

\section{Determination of the competitiveness of common-bean relative to alexandergrass}

Treatments were set in three replacement series of four replicates in a randomized block design. The total density of each replacement series was 625,816 and 1,111 plants $\mathrm{m}^{-2}$. In each series, the proportions of com- mon-bean to alexandergrass plants were 100:0 (pure stand of common-bean), 75:25, 50:50, 25:75 and 0:100\% (pure stand of alexandergrass). The desired densities were simulated by keeping 16 plants per pot in the spacing of 4.0 x $4.0 \mathrm{~cm}\left(625\right.$ plants $\left.\mathrm{m}^{-2}\right), 3.5 \times 3.5 \mathrm{~m}\left(816\right.$ plants $\left.\mathrm{m}^{-2}\right)$ and $3.0 \times 3.0 \mathrm{~m}\left(1,111\right.$ plants $\left.\mathrm{m}^{-2}\right)$. These plant spacing were obtained by using grids made of wood to facilitate the correct placement of the seeds in the desired density at equidistant points (Figure 1).

At sown $(01 / 31 / 2000)$, two seeds of commonbean and a random amount of alexandergrass seeds were placed at each pre determined spot (Figure 1). Two thinnings $(02 / 05 / 2000$ and $02 / 07 / 2000)$ were made to establish the desired densities in each treatment. At 21 days after seeding (02/21/2000), the number of plants was recorded, and the shoot of each species was separately harvested to determine the dry biomass. The common-bean plants were harvested at the V3 stage (CIAT, 1983) and the alexandergrass plants at the 14 stage (Zadoks et al., 1974). The results were analyzed qualitatively or conventionally (Harper, 1977), and quantitatively (Spitters, 1983).

\section{Qualitative analysis of the species competitiveness}

The qualitative analysis was performed for each replacement series and for the average of the three replacement series by visual interpretation of the relative yield as a function of the two species proportions. Relative yields $(\mathrm{Yr})$ of one species were calculated as dry biomass yield of that species $(Y x)$ at each proportion divided by the yield from the treatment with $100 \%$ of plants of the same species (Y) (Roush et al., 1989):

$$
Y r=\frac{Y x}{Y}
$$

Linear and quadratic regression analyses were performed with the relative yield (average of four replications) as the dependent variable and density proportions as independent variables. Each of calculated relative yield $(Y r)$ was compared to its correspondent value on the competitive equivalence line $\left(Y_{C E}\right)$. For each species, the values on the competitive equivalence line at the proportions of $0,25,50,75$ and $100 \%$ ( $\mathrm{X}$ axis) were, respectively of $0 ; 0.25 ; 0.50 ; 0.75$ and 1.00 .

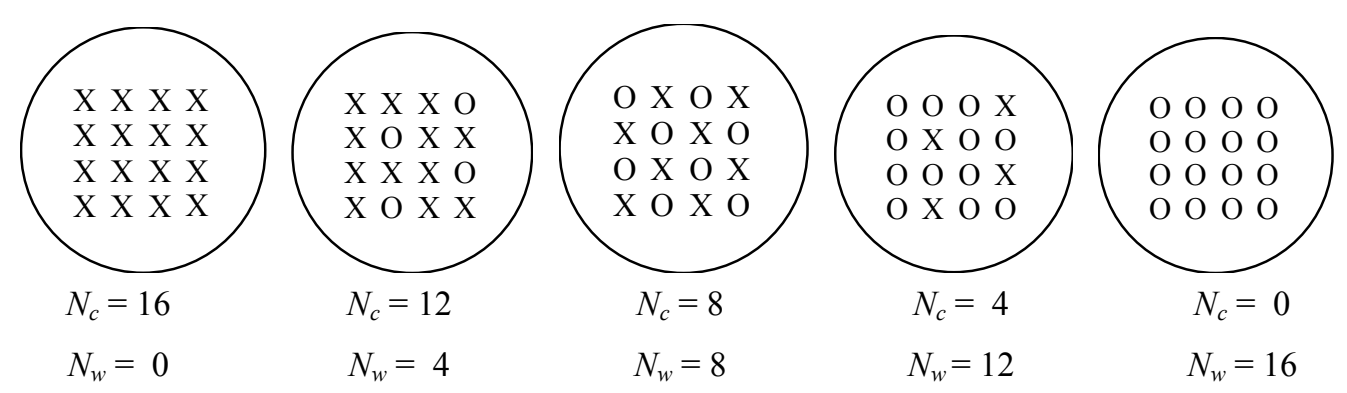

Figure 1 - Arrangement of plants in the pots for the total density of 625 plants $\mathrm{m}^{-2}(16$ plants per pot at the spacing of $4.0 \mathrm{x}$ $4.0 \mathrm{~cm}$ ). For densities of 816 and 1,111 plants $\mathrm{m}^{-2}$, the same plant arrangement was used, but reducing the spacing. $(\mathrm{N}$ - number of plants, $c$ - crop, and $w$ - weed). 
The null hypothesis $\left(H_{0}\right)$ was that differences among the means of $Y r$ and $Y_{C E}$ were similar to zero. To test $H_{0}$, it was verified at first if the values of the differences followed the normal distribution (W-test). Showing normal distribution $[(\mathrm{Pr}<\mathrm{W})>0.05]$, the comparison was made with the t-test, accepting $H_{0}$ when $[\operatorname{Pr}>|\mathrm{T}|)>0.05]$.

\section{Quantitative analysis of the species competitiveness}

Dry biomass yielded by the crop $\left(Y_{\mathrm{c}}\right)$ and the weed $\left(Y_{w}\right)$, and plant densities $\left(N_{\mathrm{c}}\right.$ and $\left.N_{w}\right)$ were used to calculate the dry biomass yielded per crop plant $\left(w_{\mathrm{c}}=Y_{\mathrm{c}}\right.$ ' $\left.N_{c}\right)$ and per weed plant $\left(w_{w}=Y_{w} / N_{w}\right)$. The reciprocal yield per plant $\left(1 / w_{\mathrm{c}}\right.$ and $\left.1 / w_{w}\right)$ were submitted to multiple linear regression analysis, with $N_{c}$ and $N_{w}$ as dependent variables, excluding those three treatments in which the species representing the dependent variable was absent, as proposed by Rejmánek et al. (1989). The obtained coefficients were used to write a pair of equations, as proposed by Spitters (1983):

$$
\begin{gathered}
\frac{1}{\mathcal{W}_{c, w}}=b_{c, o}+b_{c, c \times} N_{c}+b_{c, w \times} N_{w} \\
\frac{1}{\mathcal{W}_{w, c}}=b_{w, o}+b_{w, w \times} N_{w}+b_{w, c \times} N_{c}
\end{gathered}
$$

The first subscript of each term refers to the species which biomass is being considered, while the second subscript identifies the associated species.

The coefficients for intraspecific $\left(b_{c, c}\right.$ and $\left.b_{w, w}\right)$ and interspecific $\left(b_{c, w}\right.$ and $\left.b_{w, c}\right)$ competition were used to calculate the relative competitive ability $(R C)$ of commonbean and alexandergrass (eq.6 and eq.7), as well as the ecological niche differentiation index (NDI - eq.8), according to Spitters, (1983):

$$
\begin{aligned}
R C_{c} & =\frac{b_{c, c}}{b_{c, w}} \\
R C_{w} & =\frac{b_{w, w}}{b_{w, c}} \\
N D I & =R C_{c} \times R C_{w}
\end{aligned}
$$

There is niche differentiation when NDI exceeds unity (Spitters, 1983).

\section{RESULTS AND DISCUSSION}

\section{Density that leads to constant final yield for each species}

The coefficients from the linear regression (Table 1), were used to write the equations as the eq. (1) (Figure 2.A - common-bean and Figure 3.A - alexandergrass). Considering the biological meaning of the coefficients
(Spitters, 1983), the theoretical maximum yield of the dry weight $\left(Y_{\max }\right)$ of common-bean shoot was $958.7728 \mathrm{~g} \mathrm{~m}^{-2}$ $\left(1 / b_{1}=1 / 0.001043=958.7728\right)($ Figure 2.B) and the alexandergrass, $117.1641 \mathrm{~g} \mathrm{~m}^{-2}\left(1 / b_{1}=1 / 0.008535=\right.$ 117.1641) (Figure 3.B). For each common-bean plant added to the population, the reciprocal of the dry biomass per plant $\left(1 / w_{c, w}\right)$ has increased, or the dry biomass per plant $\left(w_{c, w}\right)$ was reduced by $0.001043 \mathrm{~g}\left(b_{l}\right)$. In the same way, for each alexandergrass plant added to the population, the reciprocal of the dry biomass per plant $\left(1 / w_{w, c}\right)$ has increased, or the dry biomass per plant $\left(w_{w, c}\right)$ was reduced by $0.008535 \mathrm{~g}$.

The reduction in the dry biomass yielded per plant when one plant was added to the population was smaller for the common-bean, indicating that this species, compared to alexandergrass, presented a lower intraspecific competition. This fact was confirmed by the intraspecific index of each species, calculated by the ratio $b_{l} / b_{0}$, which expresses the increase in $1 / w$ relative to its
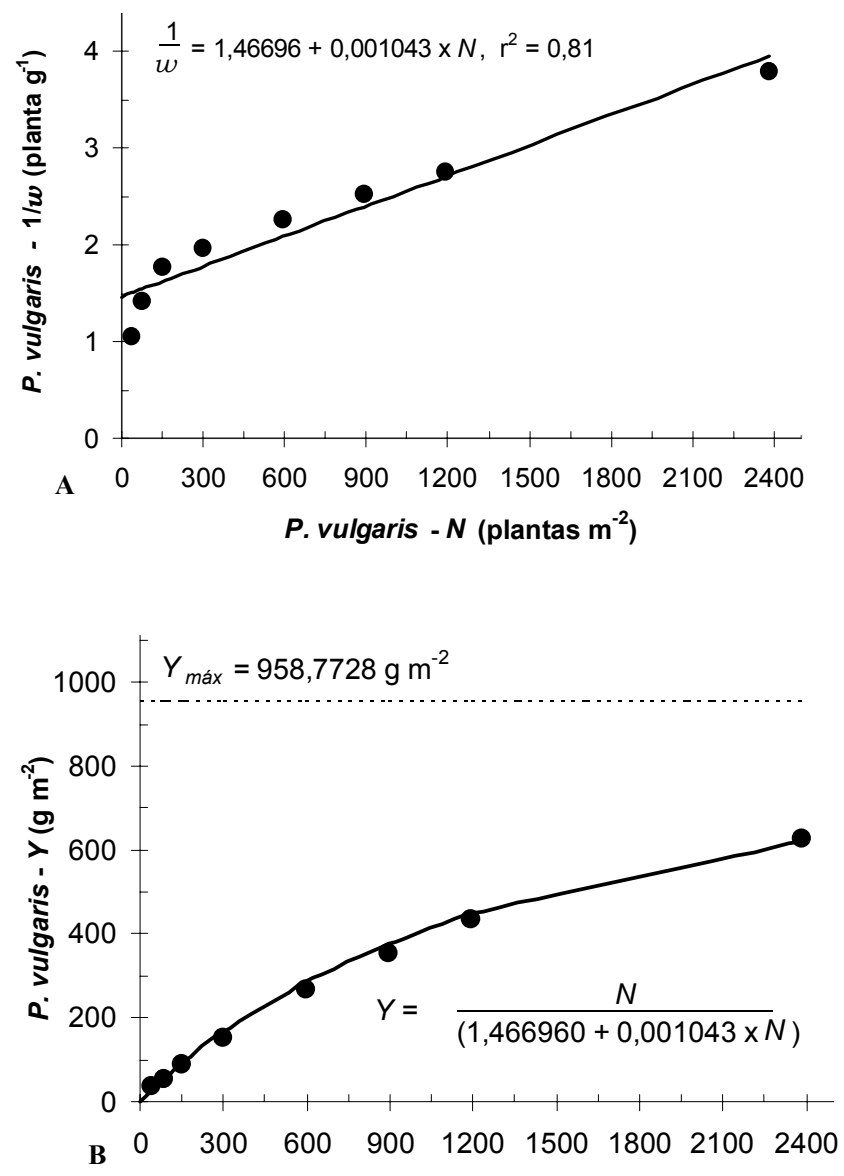

P. vulgaris $-\mathrm{N}$ (plantas $\mathrm{m}^{-2}$ )

Figure 2 - A) - Effect of the density of $P$. vulgaris $(N)$ on the reciprocal of dry biomass yielded per plant $(1 / w)$. B) Effect of the density of $P$. vulgaris $(N)$ on dry biomass yielded per area $(Y)$. 
value in the absence of competition, and can be used as a measurement of the intraspecific competition stress (Spitters, 1983). This ratio was $0.000711(0.001043 /$ $1.466960)$ for common-bean and $0.002798(0.008535 /$
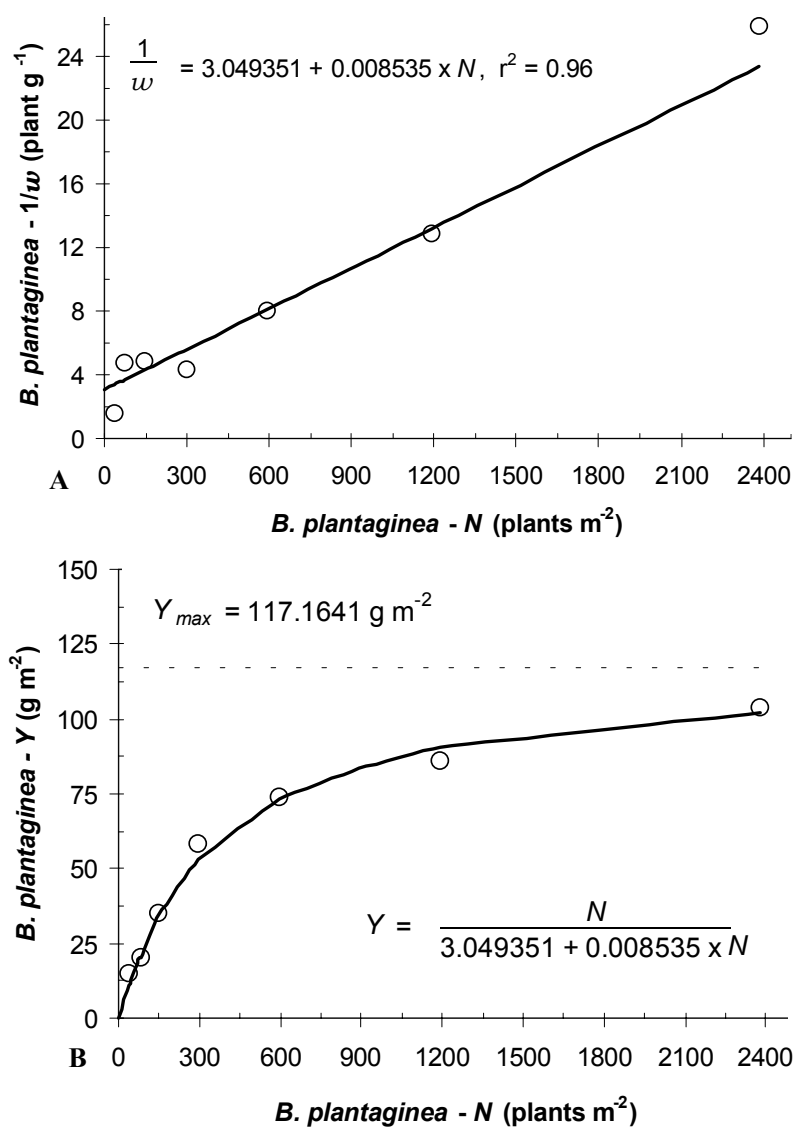

Figure 3 - A) Effect of $B$. plantaginea plant density $(N)$ on the reciprocal of dry biomass yielded per plant $(1 / w)$. B) Effect of $B$. plantaginea plant density $(N)$ on dry biomass yielded per unit area $(Y)$.
3.049351) for alexandergrass. Therefore, it would be expected that common-bean dry biomass yielded per unity area $(Y)$ would approach $Y_{\max }$ in densities higher than the alexandergrass would. For the crop, such density would be over 2,381 plants $\mathrm{m}^{-2}$ (Figure 2.B) because, up to this density, the averages of the differences among dry biomass yielded $(Y)$ and $Y_{\max }$ were different from zero (Table $2)$. This analysis suggests that either the crop dry biomass yield would continue increasing as a result of the increase in the number of plants per unit area, or that the shoot was harvested before the total competition among plants was established. There was no mention of similar results in previous papers (Roush et al., 1989; Christoffoleti \& Victoria Filho, 1996). However, while common-bean and alexandergrass were harvested three weeks after seeding, Roush et al. (1989) have harvested the wheat (Triticum aestivum L.) and the rye grass (Lolium multiflorum Lam.) after seven weeks of growth.

The minimum weed density for constant final yield, similar to the maximum yield $\left(Y_{\max }\right)$, was between 1,190 and 2,381 plants $\mathrm{m}^{-2}$ because the average of the differences among the dry biomass yielded $(Y)$ and the maximum theoretical yield $\left(Y_{\max }\right)$ was similar to zero $[(\mathrm{P}>|\mathrm{T}|)$ $=0.0720 \mathrm{~J}$ (Table 3$)$ for the highest studied density. This indicates that at higher densities, the increment in the dry biomass yield per unit area due to an increment of plants in the population will be close to zero.

From these results, three total densities were set up to carry out three replacement series treatments at one experiment. The assumption for establishment and analysis of one set of a replacement series treatment is that the total density of the species must be higher than the minimum which yield is independent of the plant density, i.e., the total density must be beyond the point of constant fi-

Table 1 - Summary of the regression analysis of the reciprocal of the dry biomass yielded per plant $\left(1 / w=p^{2} \operatorname{lant~}^{-1}\right)$ as a function of plant density $\left(N=\right.$ plants $\left.\mathrm{m}^{-2}\right)$.

\begin{tabular}{|c|c|c|c|c|}
\hline Source of variation & DF & SM & \multicolumn{2}{|c|}{ Prob $>F^{a}$} \\
\hline \multicolumn{5}{|c|}{ Phaseolus vulgaris } \\
\hline Regression & 1 & 19.18314 & \multicolumn{2}{|c|}{$1.5210^{-12}$} \\
\hline \multirow[t]{2}{*}{ Residue } & 30 & 0.144446 & \multicolumn{2}{|c|}{-} \\
\hline & Coefficient & Standard error & $\mathrm{t}^{\mathrm{c}}$ & Prob $>\mathrm{T}^{\mathrm{d}}$ \\
\hline Intercept & 1.466960 & 0.09247 & 15.86398 & $3.9210^{-16}$ \\
\hline Variable X & 0.001043 & $9.010^{-5}$ & 11.52409 & $1.5210^{-12}$ \\
\hline \multicolumn{5}{|c|}{ Brachiaria plantaginea } \\
\hline Regression & 1 & 1273.115 & \multicolumn{2}{|c|}{$3.310^{-20}$} \\
\hline \multirow[t]{2}{*}{ Residue } & 26 & 1.858565 & \multicolumn{2}{|c|}{-} \\
\hline & Coefficient & Standard error & $\mathrm{t}$ & Prob $>\mathrm{T}$ \\
\hline Intercept & 3.049351 & 0.338859 & 8.99889 & $1.8210^{-9}$ \\
\hline Variable X & 0.008535 & 0.000326 & 26.17248 & $3.310^{-20}$ \\
\hline
\end{tabular}

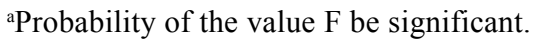

${ }^{\mathrm{b}}$ The values of the coefficient for intercept and variable $\mathrm{X}$ correspond to, respectively, the values of $b_{0}$ and $b_{1}$ of the eq. (1).

${ }^{\mathrm{c}} \mathrm{T}$ test to verify if the coefficient is similar to zero.

dProbability of the coefficient being similar to zero. 
nal yield (Wit, cited by Roush et al., 1989). Therefore, the total density of a replacement series must satisfy this assumption for both species. However, the density from which the crop would reach the constant final yield was not identified. Although the density found for alexandergrass $\left(2,381\right.$ plants $\left.\mathrm{m}^{-2}\right)$ could be used, at this density one plant occupies $4.110^{-4} \mathrm{~m}^{2}$ or $2.05 \times 2.05$ $\mathrm{cm}$. As the lower feasible spacing for equidistant plants in the used pots would be $3.0 \times 3.0 \mathrm{~cm}$, it was decided not to follow the assumption of the constant final yield. However, it was also assumed that it could have some loss in the qualitative interpretation of the results. With regard to the replacement design with more than one series, there is no scientific paper mentioning that the total density should attend the requirement of the constant final yield law. So, it was assumed that the quantitative interpretation of the results would not be affected, then the total densities in the three replacement series were set at $625 ; 816$ and 1,111 plants $\mathrm{m}^{-2}$, using the plant spacing of $4.0 \times 4.0 \mathrm{~cm}, 3.5 \times 3.5 \mathrm{~cm}$, and $3.0 \times 3.0 \mathrm{~cm}$, respectively.

\section{Determination of the competitiveness of common-bean with alexandergrass}

\section{Qualitative analysis of the species competitiveness}

There was no effect of the total density since the standard replacement series curves were qualitatively similar at each of the three total densities (data not shown). Rejmánek et al. (1989) who worked with tomato (Lycopersicon esculentum Mill.) and barnyard grass Echinochloa crus-galli var. frumentacea (Roxb.) W. F. Wight and Roush et al. (1989) who worked with wheat (Triticum aestivum L.) and rye grass (Lolium multiflorum Lam.), have observed similar results. So, analysis was performed after pooling the data of the three replacement series (Figure 4).

Table 2 - Statistical data of each treatment for the common-bean crop. Shoot dry biomass obtained at 21 days after seeding .

\begin{tabular}{|c|c|c|c|c|c|c|c|c|}
\hline \multirow{2}{*}{ Data } & \multicolumn{8}{|c|}{ Density of common-bean (plants $\mathrm{m}^{-2}$ ) } \\
\hline & 37 & 74 & 148 & 297 & 595 & 892 & 1190 & 2381 \\
\hline Mean $\left(\mathrm{g} \mathrm{m}^{-2}\right)$ & 36.99 & 54.32 & 89.47 & 153.37 & 267.86 & 356.58 & 437.67 & 688.62 \\
\hline $\begin{array}{l}\text { Mean of the difference } \\
\text { related to } Y_{\max }\left(\mathrm{g} \mathrm{m}^{-2}\right)\end{array}$ & -921.77 & -904.46 & -869.30 & -805.41 & -690.92 & -602.19 & -521.09 & -332.19 \\
\hline $\begin{array}{l}\text { Standard error of the } \\
\text { difference in related to } Y_{\max } \\
\left(\mathrm{g} \mathrm{m}^{-2}\right)\end{array}$ & 9.16 & 11.51 & 26.13 & 21.06 & 48.17 & 44.30 & 56.08 & 26.69 \\
\hline $\mathrm{CV} \%$ & -0.99 & -1.27 & -3.01 & -2.61 & -6.97 & -7.36 & -10.76 & -8.04 \\
\hline $\begin{array}{l}\text { W test }(\text { Shapiro-Wilks) } \\
(\mathrm{Pr}<\mathrm{W})\end{array}$ & $\begin{array}{c}0.98 \\
(0.9311)\end{array}$ & $\begin{array}{c}0.82 \\
(0.1317)\end{array}$ & $\begin{array}{c}0.97 \\
(0.8253)\end{array}$ & $\begin{array}{c}0.90 \\
(0.4038)\end{array}$ & $\begin{array}{c}0.87 \\
(0.2941)\end{array}$ & $\begin{array}{c}0.8801 \\
(0.3345)\end{array}$ & $\begin{array}{c}0.90 \\
(0.4101)\end{array}$ & $\begin{array}{c}0.94 \\
(0.373)\end{array}$ \\
\hline $\begin{array}{l}\text { Test } \mathrm{t}^{\mathrm{c}} \\
(\operatorname{Pr}>|\mathrm{T}|)\end{array}$ & $\begin{array}{l}-202.17 \\
(0.0001)\end{array}$ & $\begin{array}{l}-157.20 \\
(0.0001)\end{array}$ & $\begin{array}{c}-66.53 \\
(0.0001)\end{array}$ & $\begin{array}{c}-76.48 \\
(0.0001)\end{array}$ & $\begin{array}{c}-28.68 \\
(0.0001)\end{array}$ & $\begin{array}{c}-27.18 \\
(0.0001)\end{array}$ & $\begin{array}{c}-18.58 \\
(0.0003)\end{array}$ & $\begin{array}{c}-24.89 \\
(0.0001)\end{array}$ \\
\hline
\end{tabular}

The theoretical dry biomass yield $\left(Y_{\max }\right)$ calculated by the equation of the reciprocal dry biomass yielded per plant was $958.7728 \mathrm{~g} \mathrm{~m}^{-2}$.

${ }^{a}$ The common-bean was at the V3 stage (CIAT, 1983).

${ }^{\mathrm{b}}$ The data distribution of the mean of the difference related to the $Y_{\max }$ was normal when $\operatorname{Pr}<\mathrm{W}>0.05$.

${ }^{c}$ Test to verify if the means of the difference related to $Y_{\max }$ are similar to zero. Accept $H_{0}$ when $(\operatorname{Pr}>|\mathrm{T}|>0.05)$.

Table 3 - Statistical data of each treatment for alexandergrass. Shoot dry biomass yield obtained 22 days after seeding. ${ }^{\text {a }}$

\begin{tabular}{|c|c|c|c|c|c|c|c|}
\hline \multirow{2}{*}{ Data } & \multicolumn{7}{|c|}{ Density of alexandergrass (plants $\mathrm{m}^{-2}$ ) } \\
\hline & 37 & 74 & 148 & 297 & 595 & 1190 & 2381 \\
\hline Mean $\left(\mathrm{g} \mathrm{m}^{-2}\right)$ & 14.79 & 20.46 & 35.34 & 58.23 & 74.03 & 85.94 & 104.07 \\
\hline $\begin{array}{l}\text { Mean of the difference related to } \\
Y_{\max }\left(\mathrm{g} \mathrm{m}^{-2}\right)\end{array}$ & -102.38 & -96.70 & -81.82 & -58.94 & -43.13 & -31.23 & -13.09 \\
\hline $\begin{array}{l}\text { Standard error of the difference } \\
\text { related to } Y_{\max }\left(\mathrm{g} \mathrm{m}^{-2}\right)\end{array}$ & 6.12 & 6.35 & 4.22 & 18.29 & 4.77 & 6.620 & 9.59 \\
\hline $\mathrm{CV} \%$ & -5.98 & -6.57 & -5.16 & -31.03 & -11.07 & -21.20 & -73.28 \\
\hline $\begin{array}{l}\text { W test } \quad(\text { Shapiro-Wilks) } \\
(\mathrm{Pr}<\mathrm{W})\end{array}$ & $\begin{array}{c}0.93 \\
(0.5543)\end{array}$ & $\begin{array}{c}0.88 \\
(0.3407)\end{array}$ & $\begin{array}{c}0.97 \\
(0.8372)\end{array}$ & $\begin{array}{c}0.87 \\
(0.2795)\end{array}$ & $\begin{array}{c}0.96 \\
(0.7622)\end{array}$ & $\begin{array}{c}0.96 \\
(0.7480)\end{array}$ & $\begin{array}{c}0.99 \\
(0.9423)\end{array}$ \\
\hline $\begin{array}{l}\text { Test } \mathrm{t}^{\mathrm{c}} \\
(\operatorname{Pr}>|\mathrm{T}|)\end{array}$ & $\begin{array}{l}-33.44 \\
(0.0001)\end{array}$ & $\begin{array}{l}-30.46 \\
(0.0001)\end{array}$ & $\begin{array}{l}-38.78 \\
(0.0001)\end{array}$ & $\begin{array}{c}-6.44 \\
(0.0076)\end{array}$ & $\begin{array}{l}-18.07 \\
(0.0004)\end{array}$ & $\begin{array}{c}-9.43 \\
(0.0025)\end{array}$ & $\begin{array}{c}-2.73 \\
(0.0720)\end{array}$ \\
\hline
\end{tabular}

The theoretical maximum dry biomass yield $\left(\mathrm{Y}_{\max }\right)$ calculated by the equation of the reciprocal per plant yield was $117.1641 \mathrm{~g} \mathrm{~m}^{-2}$.

${ }^{a}$ Alexandergrass was at the 14 stage (Zadoks et al., 1974).

${ }^{\mathrm{b}}$ The data distribution of the mean of the difference related to the $Y_{\max }$ was normal when $\operatorname{Pr}<\mathrm{W}>0.05$.

'Test to verify if the means of the difference related to $Y_{\max }$ are similar to zero. Accept $H_{0}$ when $(\operatorname{Pr}>|\mathrm{T}|>0.05)$. 
Even though the curve of common-bean relative yield was concave (Figure 4), the averages of the differences among the observed relative yields $\left(Y_{r}\right)$ and the corresponding values of the competitive equivalence $\left(Y_{C E}\right)$ were equal to zero $(\operatorname{Pr}>|\mathrm{T}|>0,05)$ (Table 4). However, the CV was higher than $50 \%$ and, therefore, the averages of the differences could be different from zero. Considering that common-bean relative yield was higher than the competitive equivalence line, the intraspecific competition was more intense than the interespecific competition, i.e., the competitive effect among commonbean plants was higher than the competitive effect of alexandergrass over common-bean. This interpretation should be considered with some caution, since the total density for each replacement series was lower than that in which the dry biomass yielded by each species would be independent of its own density. This result could mean either that alexandergrass could have not competed with common-bean, or that the crop was in such low density that there was no intraspecific competition, and, therefore, there was yield response to density increase. Harvest made at the V3 stage has not shown intra and interespecific competition reflected on shoot dry biomass yield.

The curve of alexandergrass relative yield was convex (Figure 4). The average of the differences among the observed values and the corresponding values on the competitive equivalence line (CE) were different from zero (Table 4). So that, interspecific competition was higher than intraspecific, with disadvantage to alexandergrass, i.e., the common-bean competitive effect over alexandergrass was higher than the competition effect among alexandergrass plants.

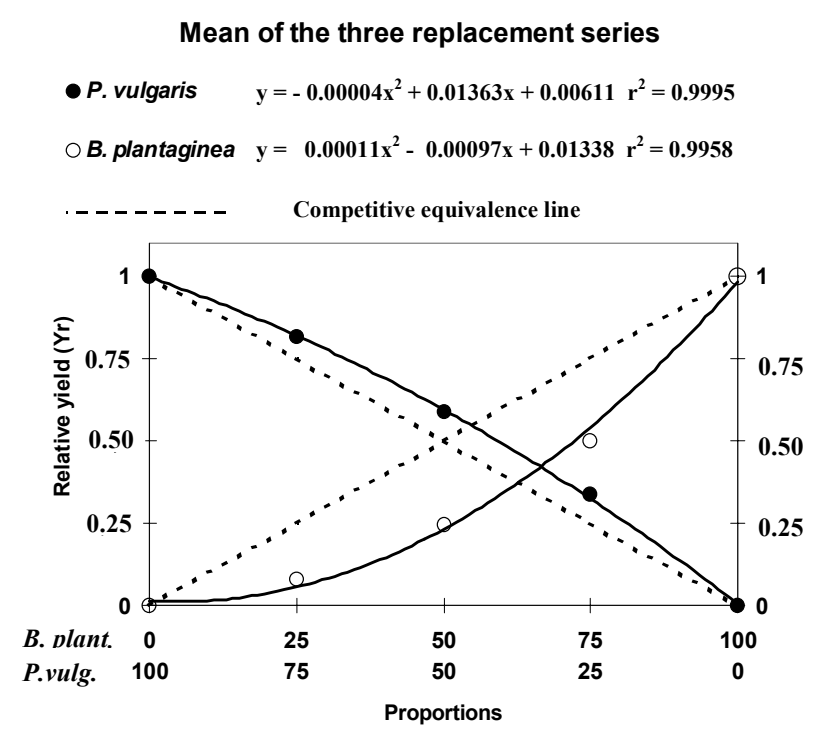

Figure 4 - Diagram of the three-replacement series average illustrating the relative yield responses of $P$. vulgaris and $B$. plantaginea to variation in species proportion. Proportions are expressed as percentage of the total density.

Table 4 - Statistical data of the difference between dry biomass relative yield and the value of the competitive equivalence (CE) in each proportion. The value of the $\mathrm{CE}$ at the proportions 75,50 and $25 \%$ was respectively, $0.75,0.50$ and 0.25 . Results obtained at 21 days after seeding. Average of the three total densities.

\begin{tabular}{|c|c|c|c|}
\hline \multirow{2}{*}{ Data } & \multicolumn{3}{|c|}{ Plant proportions $(\%)$} \\
\hline & 75 & 50 & 25 \\
\hline \multicolumn{4}{|c|}{ Phaseolus vulgaris } \\
\hline Mean of the relative yield & 0.8135 & 0.5874 & 0.3382 \\
\hline Mean of the difference related to CE & 0.0635 & 0.0874 & 0.0882 \\
\hline Standard error of the difference related to CE & 0.1260 & 0.0956 & 0.0446 \\
\hline $\mathrm{CV} \%$ & 198.524 & 109.3707 & 50.5385 \\
\hline $\begin{array}{l}\text { W test (Shapiro-Wilks) } \\
(\operatorname{Pr}<\mathrm{W})\end{array}$ & $\begin{array}{c}.8737 \\
(0.3077)\end{array}$ & $\begin{array}{c}0.9977 \\
(0.9865)\end{array}$ & $\begin{array}{c}0.8530 \\
(0.2305)\end{array}$ \\
\hline $\begin{array}{l}\text { T test }{ }^{\mathrm{b}} \\
(\operatorname{Pr}>|\mathrm{T}|)\end{array}$ & $\begin{array}{c}1.0074 \\
(0.3879)\end{array}$ & $\begin{array}{c}1.8286 \\
(0.1649)\end{array}$ & $\begin{array}{c}3.9574 \\
(0.0288)\end{array}$ \\
\hline \multicolumn{4}{|c|}{ Brachiaria plantaginea } \\
\hline Mean of the relative yield & 0.5006 & 0.2442 & 0.0782 \\
\hline Mean of the difference related to $\mathrm{CE}$ & -0.2494 & -0.2558 & -0.1718 \\
\hline Standard error of the difference related to $\mathrm{CE}$ & 0.0437 & 0.0991 & 0.0199 \\
\hline $\mathrm{CV} \%$ & -17.532 & -38.7289 & -11.6028 \\
\hline $\begin{array}{l}\text { W test (Shapiro-Wilks) } \\
(\operatorname{Pr}<W)\end{array}$ & $\begin{array}{c}0.8464 \\
(0.2991)\end{array}$ & $\begin{array}{c}0.8681 \\
(0.2855)\end{array}$ & $\begin{array}{c}0.8985 \\
(0.4180)\end{array}$ \\
\hline $\begin{array}{l}\text { T test } \\
(\operatorname{Pr}>|\mathrm{T}|)\end{array}$ & $\begin{array}{l}-11.408 \\
(0.0014) \\
\end{array}$ & $\begin{array}{l}-5.1641 \\
(0.0141) \\
\end{array}$ & $\begin{array}{r}-17.2372 \\
(0.0004) \\
\end{array}$ \\
\hline
\end{tabular}

${ }^{a}$ The distribution of the mean difference related to $\mathrm{CE}$ data was normal when $(\operatorname{Pr}<\mathrm{W})>0.05$.

${ }^{\mathrm{b}}$ The data distribution of the mean of the difference related to the $Y_{\max }$ was normal when $(\operatorname{Pr}<\mathrm{W})>0.05$.

'Test to verify if the means of the difference related to $Y_{\max }$ are similar to zero. Accept $H_{0}$ when $\left.(\operatorname{Pr}>\mid \mathrm{T})>0.05\right)$. 
In some occasions, two species which have similar requirements for natural resources can differ in their responses (Harper, 1977). The more aggressive species contributes more than the expected to the total yield, while the other contributes less than expected. Therefore, one curve is concave and the other is convex, indicating that the interaction between these species is for the same natural resources, but one species is more efficient in capturing them from the environment. Common-bean have probably captured the resources with more efficiency than alexandergrass (Figure 4), and so, common-bean was interpreted as a superior competitor. Although plants height and leaf area have not been evaluated as Rejmánek et al. (1989) had done, plants of common-bean were observed to emerge first and grow faster than alexandergrass did, presenting higher plants and bigger leaf area which could have contributed for its better competitive performance.

\section{Quantitative analysis of the species competitiveness}

The responses of the reciprocal of dry biomass yielded per plant of common-bean and per plant of alexandergrass to the their own density and to the density of the competitor species are presented in Figures 5 and 6. A summary of the regression analysis is presented in Table 5. The three-dimensional surface of each graphic represents the expected values derived from the experimental data.

The reciprocal of the dry biomass yielded by common-bean $\left(1 / w_{c, w}\right)$ has increased by increasing the density of its plants $\left(N_{c}\right)$ (Figure 5). By the regression equa- tion (eq. 4), according to Spitters (1983), the coefficient of the crop density $\left(b_{c, c}=0.00064\right)$ quantifies the competition among common-bean plants (intraspecific competition) and the coefficient of the weed density $\left(b_{c, w}=\right.$ 0.00003 ) quantifies the effect of alexandergrass over common-bean (interspecific competition). The relative competitive ability (RC) of the species which dry biomass is being considered, in this case the crop, in relation to another species is defined by the ratio of the regression coefficients $b_{c, c} / b_{c, w}$. Adding one common-bean plant has had an equal effect on the reciprocal of the dry biomass per crop plant $\left(1 / w_{c, w}\right)$ as adding 21.3 alexandergrass plants $(21.3=0.00064 / 0.00003)$. In another words, the addition of one common-bean plant has increased $1 / w_{c w}$, i.e., reduced the crop yield per plant $\left(w_{c, w}\right)$ to the same extent as the addition of 21.3 alexandergrass plants. One commonbean plant has sensed the presence of another commonbean plant as strongly as the presence of 21.3 alexandergrass plants. However, the probability of the interspecific competition $\left(b_{c w}\right)$ being similar to zero was $91 \%$ (Table 5), meaning that there is $91 \%$ chance that the weed could have not interfered on common-bean dry biomass.

The reciprocal of the dry biomass per alexandergrass plant was reduced as this species density was increased and it was increased as the common-bean density was increased (Figure 6). The negative signal of the coefficient $b_{w, w}$ indicates that at each alexandergrass plant increment in the mixture of plants, $1 / w_{w, c}$ decreased, or $w_{w, c}$ increased by $0.01574 \mathrm{~g}$.

Table 5 - Summary of the multiple linear regression analysis of the reciprocal of dry biomass yielded per plant of commonbean (P. vulgaris) $\left(1 / w_{c, w}\right)$ and of alexandergrass (B. plantaginea) $\left(1 / w_{p d, c}\right)$ as a function of the density of the two species $\left(N_{c}\right.$ and $\left.N_{w}\right)$.

\begin{tabular}{|c|c|c|c|c|}
\hline Source of Variation & DF & MS & \multicolumn{2}{|c|}{ Prob $>$ F } \\
\hline \multicolumn{5}{|c|}{ Phaseolus vulgaris } \\
\hline Regression & 2 & 0.1700 & \multicolumn{2}{|c|}{0.0239} \\
\hline Residue & 9 & 0.0292 & \multicolumn{2}{|c|}{-} \\
\hline $\mathrm{CV}$ & 10.5856 & - & - & - \\
\hline \multirow[t]{2}{*}{$\mathrm{R}^{2}$} & 0.5639 & - & - & - \\
\hline & Coefficient & Standard error & $\mathrm{t}$ & Prob $>\mathrm{T}$ \\
\hline Intercept & 1.26673 & 0.21567 & 5.87326 & 0.00024 \\
\hline Variable $N_{c}$ & 0.00064 & 0.00026 & 2.45956 & 0.03618 \\
\hline Variable $N_{w}$ & 0.00003 & 0.00028 & 0.11741 & 0.90910 \\
\hline \multicolumn{5}{|c|}{ Brachiaria plantaginea } \\
\hline Regression & 2 & 541.4422 & \multicolumn{2}{|c|}{0.000837} \\
\hline Residue & 9 & 31.43026 & \multicolumn{2}{|c|}{-} \\
\hline $\mathrm{CV}$ & 24.71 & - & - & - \\
\hline \multirow[t]{2}{*}{$\mathrm{R}^{2}$} & 0.7929 & - & - & - \\
\hline & Coefficient & Standard error & $\mathrm{T}$ & Prob $>\mathrm{T}$ \\
\hline Intercept & 23.67577 & 7.07402 & 3.34686 & 0.00857 \\
\hline Variable $N_{c}$ & 0.02314 & 0.00909 & 2.54443 & 0.03148 \\
\hline Variable $N_{w}$ & -0.01574 & 0.00847 & -1.8583 & 0.09592 \\
\hline
\end{tabular}


Reciprocal of $P$. vulgaris biomass

$$
1 / w_{c, w}=1.26673+0.00064 \times N_{c}+0.00003 \times N_{w} \quad r^{2}=0.56
$$

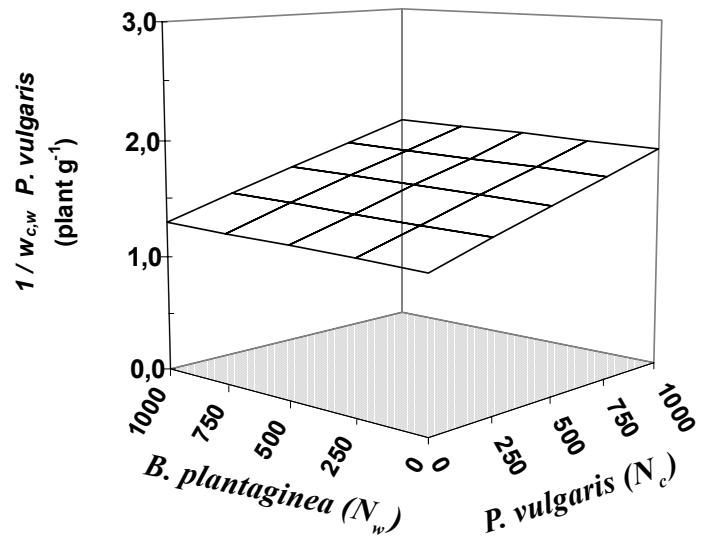

Figure 5 - Combined effects of weed density $\left(N_{w}\right)$ (alexandergrass, $B$. plantaginea) and crop density $\left(N_{c}\right)$ (common-beans, $P$. vulgaris) on the reciprocal of dry biomass per commonbean plant $\left(1 / w_{c, w}\right)$ (eq. 4$)$.

Even though not evaluated, the higher the alexandergrass density, the smaller its plants were and less leaves the plants had. It is possible that alexandergrass plants have recruited lower amount of resources from the environment than common-bean and, even though they had their growth stunted, they had more amount of dry biomass accumulated. The weed density coefficient $\left(b_{w, w}=0.01574\right)$ quantifies the competition among alexandergrass plants and the crop density coefficient $\left(b_{w, c}=0.02314\right)$ quantifies the effect of the common-bean competition over alexandergrass. Alexandergrass has sensed the presence of one plant of the same species as strongly as the presence of 0.68 common-bean plants $\left(b_{w, w} / b_{c, w}\right)$. As the crop relative competitive ability $\left(\mathrm{RC}_{\mathrm{c}}\right.$, eq. 6) was 21.3 and the weed relative competitive ability $\left(\mathrm{RC}_{\mathrm{w}}\right.$, eq. 7$)$ was 0.68 , both species have suffered lower degree of competition with alexandergrass as neighbor.

There was ecological niche differentiation because the product between the two species relative competitive ability (eq. 8 ) was 14.48 . However, the niche differentiation was partial since the common-bean intraspecific competition was higher than the competition imposed by alexandergrass plants over common-bean, at the same time that the competition imposed by common-bean plants over alexandergrass was higher than the alexandergrass intraspecific competition. Therefore, although the species have competed for the same resources, common-bean plants have probably captured environmental resources more efficiently than alexandergrass plants. Spitters (1983) found niche differentiation between corn and peanut and stated that the niche differentiation is very
Reciprocal of $B$. plantaginea dry biomass

$$
1 / w_{\mathrm{w}, \mathrm{c}}=23.67577-0.01574 \times N_{w}+0.02314 \times N_{c} \quad r^{2}=0.79
$$

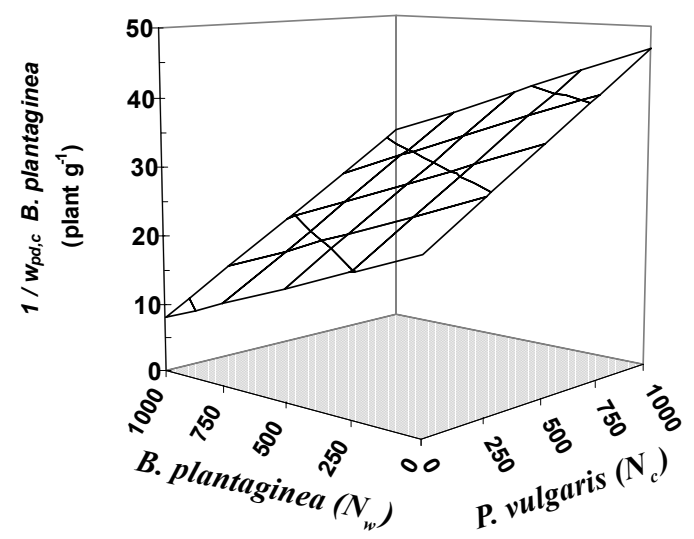

Figure 6 - Combined effects of weed density $\left(N_{w}\right)$ (alexandergrass, B. plantaginea) and crop density $\left(N_{c}\right)$ (common-bean, $P$. vulgaris) on the reciprocal of the dry biomass per alexandergrass plant (eq. 5).

common when legume and grass plants are mixed. It is very likely that this statement can be generalized for the niche differentiation between common-bean and grass weeds.

While the qualitative analysis showed no difference of the relative competitiveness of the species relative to plant densities, the quantitative analysis detected a significant effect of the plant density. Roush et al. (1989) also found this contradiction. The authors have suggested that the qualitative method was less sensitive in detecting possible influences of density on competitive interactions, and that this difference in the sensitivity of the methods may have resulted from data transformation. While the qualitative method uses the relative yield, the quantitative method is performed on the reciprocal of yield per plant.

By the qualitative method, when the commonbean relative yield is considered, the competition among common-bean plants was either null or higher than the effect of alexandergrass plants over common-bean, and the alexandergrass competitive effect over common-bean was either null or similar to the common-bean intraspecific competition. When alexandergrass relative yield is considered, the common-bean competitive effect on alexandergrass was higher than alexandergrass intraspecific competition. So that, the common-bean relative yield was either superior or similar to the competitive equivalence line, and the alexandergrass relative yield was inferior to this line. Therefore, common-bean, as a competitor species, was superior to alexandergrass. By the quantitative method, it was evident that there was commonbean intraspecific competition and that the weed (14 
stage) affected very little the common-bean plants (V3 stage). It was confirmed that there was no competition effects among alexandergrass plants; that the crop effect over the weed was higher than the competitive effect among alexandergrass plants, and that the ecological niche differentiation was partial, since the crop intraspecific competition was higher than the interspecific, being the latter not significant, and the weed interspecific competition was higher than the intraspecific competition.

\section{LITERATURE CITED}

CHRISTOFFOLETI, P.J.; VICTORIA FILHO, R. Efeitos da densidade e proporção de plantas de milho (Zea mays L.) e caruru (Amaranthus retroflexus L.) em competição. Planta Daninha, v.14, p.42-47, 1996.

CIAT. Etapas de desarrollo de la planta de fríjol común; guía de estudio para ser usada como complemento de la Unidad audiotutorial sobre el mismo tema. Cali, Colombia: CIAT, 1983. 26. (Serie O4SB-09.03)

CONNOLY, J. Experimental methods in plants competition research in cropweed systems. Weed Research, v.28, p.437-441, 1988.

COUSENS, R. Aspects of the design and interpretation of competition (interference) experiments. Weed Technology, v.5, p.664-673, 1991.
HARPER, J.L. Population biology of plants. London: Academic Press, 1977. 892p.

JOLLIFFE, P.A.; MINJAS, A.N.; RUNECKLES, V.C. A reinterpretation of yield relationships in replacement series experiments. Journal of Applied Ecology, v.21, p.227-243, 1984.

OLIVER, L.R.; BUCHANAN, G.A. Weed competition and economic thresholds. In: CAMPER, N.D. (Ed.) Research methods in weed science. s1.: Southern Weed Science Society of America, 1986. cap.4, p. $72-97$.

REJMÁNEK, M.; ROBINSON, G.R.; REJMÁNKOVÁ, E. Weed-crop competition: experimental designs and models for data analysis. Weed Science, v.37, p.276-284, 1989.

ROUSH, M.L.; RADOSEVICH, S.R.; WAGNER, R.G.; MAXWELL, B.D.; PETERSEN, T.D. A comparison of methods for measuring effects of density and proportion in plant competition experiments. Weed Science, v.37, p.268-275, 1989.

SPITTERS, C.J.T. An alternative approach to the analysis of mixed cropping experiments. 1. Estimation of competition effects. Netherlands Journal of Agricultural Science, v.31, p.1-11, 1983

ZADOKS, J.C.; CHANG, T.T.; KONZAK, C.F. A decimal code for the growth stages of cereals. Weed Research, v.14, p.415-421, 1974.

Received December 07, 2001 